\title{
Primary small cell carcinoma of the urinary bladder
}

\author{
Sumaira Qayoom, ${ }^{1}$ Deep Chakrabarti 다, ${ }^{2}$ Fatima Khan, ${ }^{1}$ Madhu Mati Goel ${ }^{1}$
}

${ }^{1}$ Department of Pathology, King George's Medical University, Lucknow, Uttar Pradesh, India ${ }^{2}$ Department of Radiotherapy, King George's Medical University, Lucknow, Uttar Pradesh, India

\section{Correspondence to} Dr Deep Chakrabarti, deepchakrabarti.19@gmail.com

Accepted 27 August 2019

Check for updates

(c) BMJ Publishing Group Limited 2019. No commercial re-use. See rights and permissions. Published by BMJ.

To cite: Qayoom $S$, Chakrabarti D, Khan F, et al. BMJ Case Rep

2019:12:e230185.

doi:10.1136/bcr-2019-

230185

\section{SUMMARY}

Small cell carcinoma of the urinary bladder (SCCB) is an extremely rare but aggressive tumour constituting less than $0.7 \%$ of all urinary bladder tumours. It is often misdiagnosed as transitional cell carcinoma, owing to the similarities in presentation. Diagnosis of SCCB is based on the WHO criteria for small cell lung carcinoma. A 58-year-old man who had presented with haematuria and burning micturition for 3 months was initially diagnosed as high-grade muscle-invasive urothelial carcinoma based on the TURBT specimen. The patient was put on neoadjuvant chemotherapy, but presented again with haematuria and back pain after 3 months. Imaging studies showed a lesion in the posterolateral wall of the urinary bladder, along with partial collapse and anterior wedging of $\mathrm{L} 1$ vertebra. He underwent TURBT, and on the basis of histopathology and immunohistochemistry, a diagnosis of primary SCCB bladder with vertebral metastasis was made.

\section{BACKGROUND}

Small cell carcinoma of the urinary bladder (SCCB) is an extremely rare but aggressive entity constituting less than $0.7 \%$ of all urinary bladder tumours. ${ }^{1}$ Its clinical features and presenting symptoms are similar to those of transitional cell carcinoma. Hence, it is often misdiagnosed. Establishing a correct diagnosis is, however, important due to its therapeutic and prognostic implications. Diagnosis of SCCB is based on the WHO criteria for small cell lung carcinoma. ${ }^{1}$ We present a case of primary small cell carcinoma of the urinary bladder with vertebral metastases in a 58-year-old man, misdiagnosed initially as high-grade urothelial carcinoma.

\section{CASE PRESENTATION}

A 58-year-old man was referred to the oncology outpatient department with complaints of haematuria and burning micturition for 3 months. On cystoscopy, a mass had been identified in the urinary bladder, and a diagnosis of high-grade urothelial carcinoma, muscle invasive, had been made based on the trans urethral resection of bladder tumour (TURBT) specimen. The patient was put on neoadjuvant chemotherapy but presented again at 3 months with haematuria and low back pain.

\section{INVESTIGATIONS}

Contrast-enhanced CT scan (CECT) of the abdomen showed a heterogeneously enhancing proliferative lesion involving the right posterolateral wall of the urinary bladder. The lesion was seen involving extravesical fat planes (figure 1A). Imaging of the lungs was unremarkable.

MRI of the spine showed partial collapse and anterior wedging of the L1 vertebrae with an expansile soft-tissue lesion affecting its left half (figure 1B).

Histopathology-TURBT was performed again and histopathology revealed sheets and nests of small to medium-sized cells with hyperchromatic nuclei, inconspicuous nucleoli and scant cytoplasm with extensive areas of coagulative necrosis. Focal spindling was also noted (figure 2).

Immunohistochemistry revealed tumour cells strongly positive for cytokeratin 7 and synaptophysin while negative for cytokeratin 20 and p63 (figure 3).

\section{DIFFERENTIAL DIAGNOSIS}

The differential diagnosis included high-grade urothelial carcinoma and metastases from small cell lung carcinoma. As the cells were negative for cytokeratin 20 and p63 while being positive for synaptophysin and cytokeratin 7, hence, high- grade urothelial carcinoma was ruled out. Imaging did not reveal any lesion in the lungs, so a metastatic small cell carcinoma was ruled out, and a diagnosis of primary small cell carcinoma was arrived at.

\section{TREATMENT}

Due to vertebral metastasis, the patient was put on platinum-based palliative chemotherapy. $\mathrm{He}$ also received palliative radiotherapy to the spine to alleviate symptoms of pain.

\section{OUTCOME AND FOLLOW-UP}

The patient succumbed to the disease within 1 month of beginning chemotherapy.

\section{DISCUSSION}

Urinary bladder carcinoma is the 10th most common malignancy worldwide. ${ }^{12}$ However, in India, its incidence is low and it represents only $1.8 \%$ of newly diagnosed cases of cancer. ${ }^{3}$ Urothelial carcinoma makes up more than $90 \%$ of urinary bladder cancers, followed by squamous cell carcinoma (SqCC) and adenocarcinoma. ${ }^{4}$ Neuroendocrine tumours are uncommon, and are classified as carcinoid tumour and neuroendocrine carcinoma. Neuroendocrine carcinoma is further classified as small cell carcinoma (SCC) and large cell carcinoma. ${ }^{5}$

Small cell carcinoma of the urinary bladder (SCCB), which was first described in 1981 by Cramer et al, ${ }^{6}$ is an uncommon entity constituting approximately $1 \%$ 


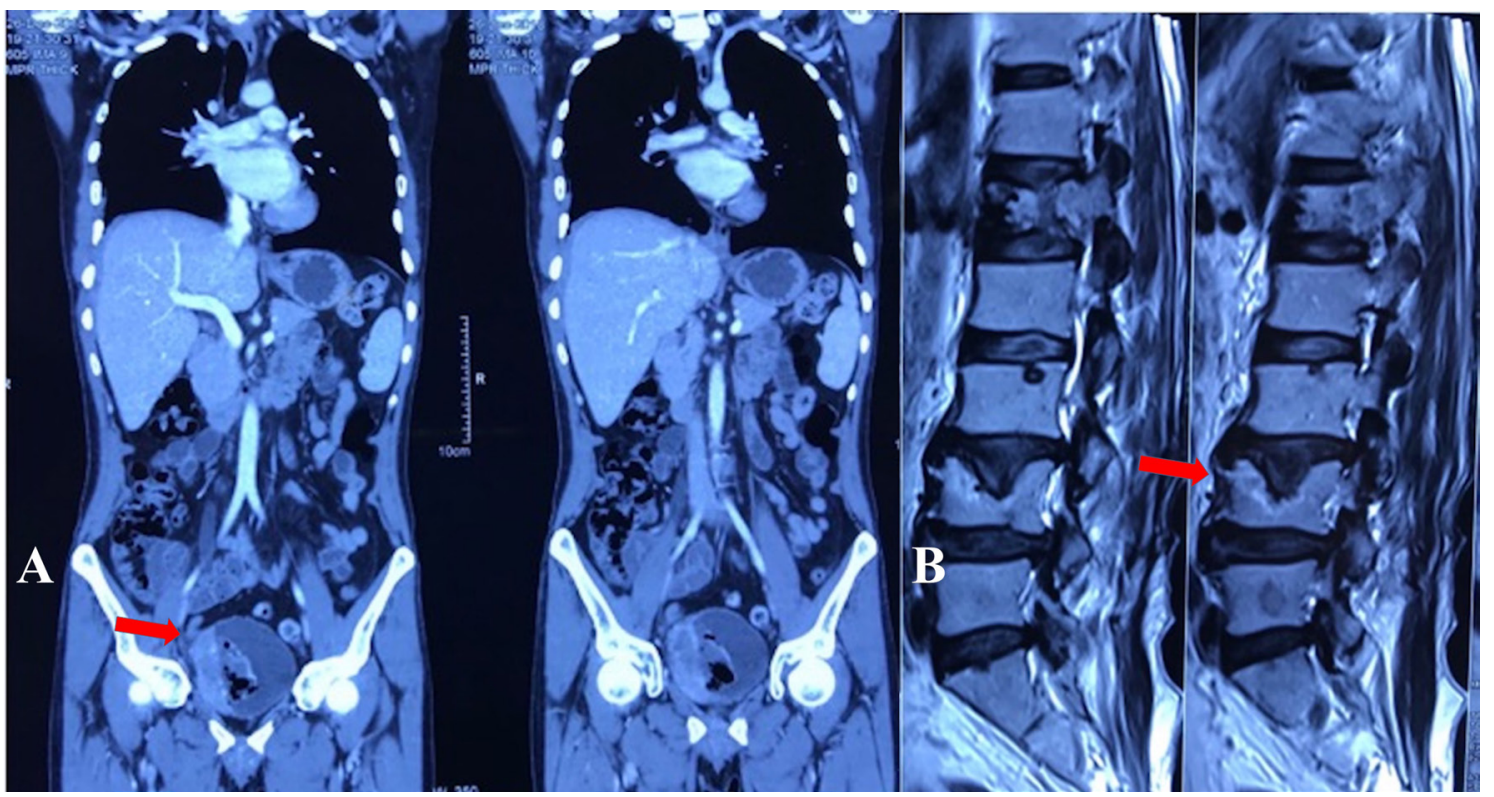

Figure 1 (A) Contrast-enhanced CT scan of the abdomen showing a heterogeneously enhancing proliferative lesion involving right posterolateral wall of urinary bladder measuring approximately $74 \times 54 \times 63 \mathrm{~mm}$. The lesion was involving extravesical fat planes (arrow in Panel A). (B) MRI of the spine showing partial collapse and anterior wedging of L1 vertebra with expansile soft-tissue lesion affecting its left half (arrow in Panel B).

of bladder cancer cases. ${ }^{7}$ However, urinary bladder is the most common site for extra pulmonary SCC in the genitourinary tract. ${ }^{8}$ As the clinical and cystoscopic features are similar to urothelial carcinoma, the diagnosis is based on histopathological examination as defined by the WHO guidelines for small cell lung carcinoma. Bladder small cell carcinoma is usually not associated with paraneoplastic syndromes as seen in lung. ${ }^{4}$ Microscopically, the tumour cells are usually arranged in sheets, occasionally in nests and trabeculae with nuclear crowding or moulding, and significant necrosis. Individual tumour cells are seen with inconspicuous nucleoli, finely stippled chromatin and scant cytoplasm. SCCB can be of pure or mixed histology, as seen in 40\%-50\% of cases. ${ }^{5}$ This has been variably reported as a prognostic factor, however, the largest study from India did not find so. ${ }^{9}$ The fact that the most common mixed component is conventionally

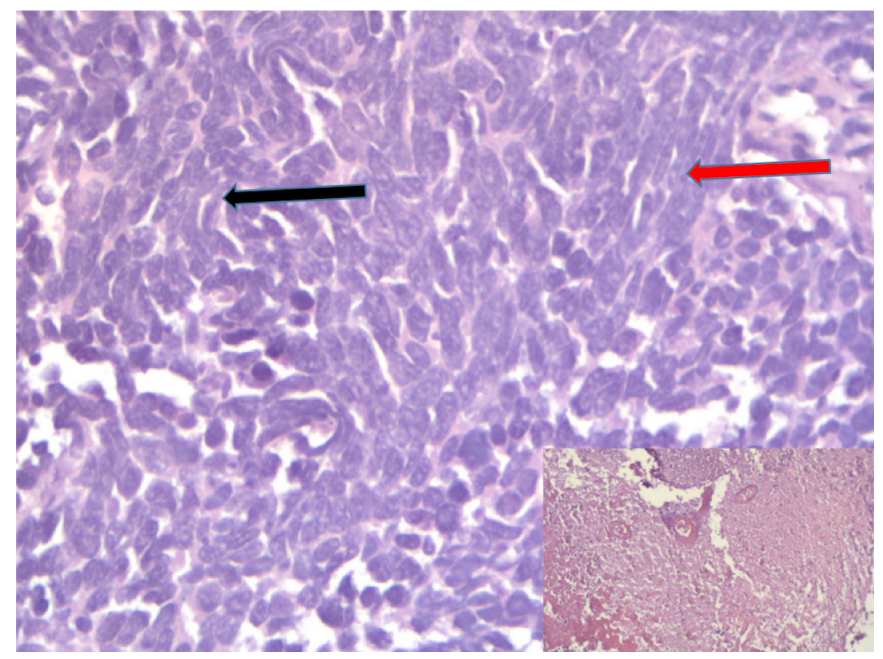

Figure 2 Sheets and nests of small to medium-sized cells with hyperchromatic nucleui, inconspicuous nucleoli and scant cytoplasm (black arrow) with extensive areas of coagulative necrosis (shown in inset). Areas of spindling are also seen (red arrow) (H \&E $\times 400)$. urothelial carcinoma has led to the proposal of a common origin of both tumours, where SCCB represents the dedifferentiated form of urothelial carcinoma. ${ }^{1}$ In our case, the initial TURBT was diagnosed as a high-grade urothelial carcinoma which could either be a misdiagnosis due to the rarity of the small cell carcinoma component, or due to the presence of a mixed histology where the high-grade urothelial carcinoma component had responded to chemotherapy, leaving behind residual small cell carcinoma. There have been few cases reported where transdifferentiation of urothelial carcinoma to small cell carcinoma had occurred after intravesical Bacillus Calmette-Guérin (BCG) instillation and chemotherapy. ${ }^{10}$ However, the reported time for this transdifferentiation has been reported at around 24-164 months, which was not seen in our case. ${ }^{11}$

As the biological behaviour of SCCB is highly aggressive as compared with stage-matched bladder urothelial carcinoma, ${ }^{1}$ it is important to differentiate the two. Even though the WHO has made it permissible to make the diagnosis on morphological ground alone, ${ }^{12}$ immunohistochemistry still plays an important role. The tumour cells are positive for neuroendocrine markers like synaptophysin, chromogranin, neuron-specific enolase (NSE), and CD56. It has been observed that NSE is the most sensitive marker showing positivity in $80 \%$ of cases, ${ }^{13}$ followed by CD56 staining in $71.4 \%$ of cases. ${ }^{14}$ SCCB is usually positive for CK7 and negative for CK20, but it is important to note that about $50 \%$ of high-grade urothelial carcinomas can be negative for CK20. ${ }^{15} \mathrm{P} 63$ is negative in $92.8 \%$ cases of SCCB and positive in $81.3 \%$ cases of high-grade urothelial carcinomas, and can be a reliable marker to differentiate the two. ${ }^{14}$ It is worth mentioning that $20 \%-40 \%$ cases of SCCB are positive for TTF-1 and this should not be erroneously diagnosed as metastases from the lung. ${ }^{13} \mathrm{P} 16$ staining is seen in approximately $92.8 \%$ of SCCB and $43.7 \%$ of high-grade urothelial carcinomas. ${ }^{14}$ In view of 16 negativity, the diagnosis of SCCB should be given with caution. Uroplakin is negative in $100 \%$ of cases of SCCB, while CD44v6 is expressed in 6.8\% cases of SCCB and 57\% cases of urothelial carcinoma. ${ }^{16}$ Thus, the diagnostic immune profile of SCCB differentiating from high-grade urothelial carcinoma is uroplakin (-), p16 (+), p63 (-) and CK20 (-). 


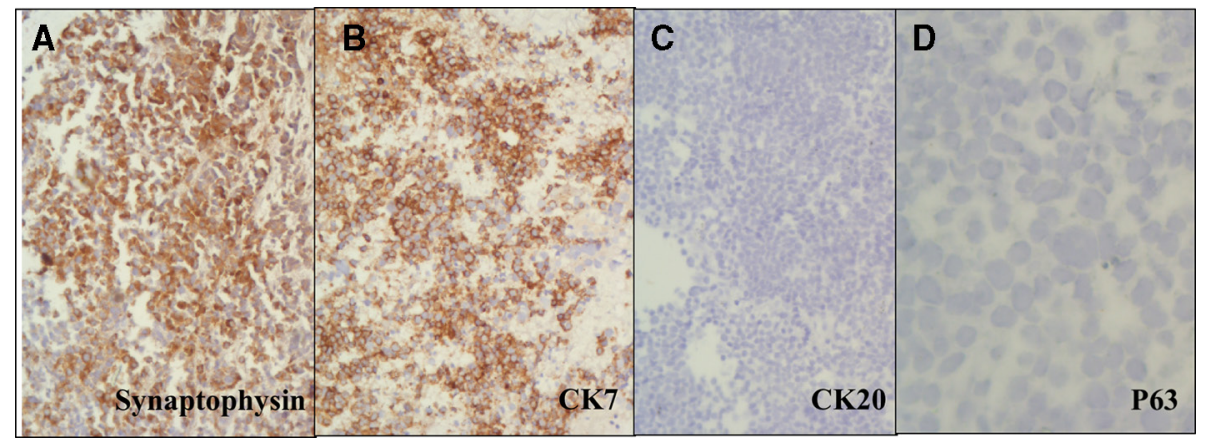

Figure 3 Tumour cells positive for synaptophysin (A), strongly positive for cytokeratin 7(B), while negative for cytokeratin 20 (C) and p63 (D). $(\times 200)$.

The prognosis of SCCB is poorer than urothelial carcinoma with a median survival reported between 10 and 20 months, and a 5 year overall survival (OS) in 5\%-20\% of cases. ${ }^{6}{ }^{17}$ Due to low incidence of this entity, standard guidelines for management are yet to be established. Neoadjuvant chemotherapy, followed by surgical resection and adjuvant chemotherapy, has shown the best results in improving the OS and disease-free survival (DFS). Definitive chemoradiotherapy is used for surgically unfit or ineligible patients, and may be considered as part of a patient's preference. ${ }^{18}$ Indeed, primary chemoradiation offers good locoregional control even in locally advanced disease, and can be an alternative to surgery when organ preservation is the aim. ${ }^{19}$ Metastatic disease is managed by palliative chemotherapy. Radiotherapy can be used in a palliative setting for local haemostatic control or to alleviate bone pain in metastatic disease. Unlike in small cell lung carcinoma, the role of prophylactic cranial irradiation is unclear. ${ }^{1718}$

\section{Learning points}

- Primary small cell carcinoma of the urinary bladder is an extremely rare tumour, that should always be considered as a differential diagnosis of high-grade urothelial carcinoma because of its aggressive nature and high metastatic potential.

- Diagnosis is achieved by histopathological examination with immunohistochemistry.

- Neoadjuvant chemotherapy followed by surgery offers the best chance at curative treatment. Primary chemoradiation offers good locoregional control with a functioning bladder.

- Palliative chemotherapy with or without radiotherapy is used in a metastatic setting.

\section{Twitter deep 190690}

Contributors SQ conceived the case report, performed histopathology and IHC examination, and wrote the manuscript. DC was involved in patient treatment, image acquisition and helped in writing the manuscript. FK helped in image acquisition, and HPE and IHC reporting. MMG provided clinical oversight and expertise. All authors read and approved the final draft.

Funding The authors have not declared a specific grant for this research from any funding agency in the public, commercial or not-for-profit sectors.

Competing interests None declared.

Patient consent for publication Next of kin consent obtained.

Provenance and peer review Not commissioned; externally peer reviewed.

ORCID ID

Deep Chakrabarti http://orcid.org/0000-0002-9511-6844

\section{REFERENCES}

1 Zhao X, Flynn EA. Small cell carcinoma of the urinary bladder: a rare, aggressive neuroendocrine malignancy. Arch Pathol Lab Med 2012;136:1451-9.

2 Bray F, Ferlay J, Soerjomataram I, et al. Global cancer statistics 2018: GLOBOCAN estimates of incidence and mortality worldwide for 36 cancers in 185 countries. CA Cancer J Clin 2018:68:394-424.

3 World Health Organization. Global Health Observatory. Geneva: World Health Organization, 2018. who.int/gho/database/en/

4 Sehgal SS, Wein AJ, Bing Z, et al. Neuroendocrine tumor of the bladder. Rev Urol 2010;12:e197-201.

5 Mazzucchelli R, Morichetti D, Lopez-Beltran A, et al. Neuroendocrine tumours of the urinary system and male genital organs: clinical significance. BJU Int 2009;103:1464-70.

6 Thota S, Kistangari G, Daw H, et al. A clinical review of small-cell carcinoma of the urinary bladder. Clin Genitourin Cancer 2013;11:73-7.

7 Koay EJ, Teh BS, Paulino AC, et al. A Surveillance, Epidemiology, and End Results analysis of small cell carcinoma of the bladder: epidemiology, prognostic variables, and treatment trends. Cancer 2011;117:5325-33.

8 Mukesh M, Cook N, Hollingdale AE, et al. Small cell carcinoma of the urinary bladder: a 15-year retrospective review of treatment and survival in the Anglian Cancer Network. BJU Int 2009;103:747-52.

9 Ram D, Rajappa S, Babu Koyyala V, et al. Small cell carcinoma of urinary bladder: Analysis from a tertiary cancer care center of India. Indian Journal of Medical and Paediatric Oncology 2018;39:326-30.

10 Morozumi K, Namiki S, Kudo T, et al. Transdifferentiation of Small Cell Carcinoma of the Urinary Bladder from Urothelial Carcinoma after Transurethral Resection of a Bladder Tumor, Intravesical Bacillus Calmette-Guerin Instillation, and Chemotherapy: A Case Report. Case Rep Oncol 2016;9:786-91.

11 Goto K, Hayashi T, Inoue Y, et al. Small cell carcinoma occurring after treatment for urothelial cell carcinoma of the urinary bladder: a case report. Nishinihon J Urol 2010;72:697-700.

12 Eble JN, Sauter G, Epstein JI, et al. Pathology and Genetics of Tumours of the Urinary System and Male Genital Organs. World Health Organization Classification of Tumours. . Lyon, France: IARC Press, 2004:vol 6. 135-6.

13 Soriano P, Navarro S, Gil M, et al. Small-cell carcinoma of the urinary bladder. A clinico-pathological study of ten cases. Virchows Arch 2004;445:292-7.

14 Buza N, Cohen PJ, Hui P, et al. Inverse p16 and p63 expression in small cell carcinoma and high-grade urothelial cell carcinoma of the urinary bladder. Int J Surg Pathol 2010;18:94-102.

15 Jones TD, Kernek KM, Yang XJ, et al. Thyroid transcription factor 1 expression in small cell carcinoma of the urinary bladder: an immunohistochemical profile of 44 cases. Hum Pathol 2005;36:718-23.

16 Iczkowski KA, Shanks JH, Allsbrook WC, et al. Small cell carcinoma of urinary bladder is differentiated from urothelial carcinoma by chromogranin expression, absence of CD44 variant 6 expression, a unique pattern of cytokeratin expression, and more intense gamma-enolase expression. Histopathology 1999;35:150-6.

17 Lynch SP, Shen Y, Kamat A, et al. Neoadjuvant chemotherapy in small cell urothelial cancer improves pathologic downstaging and long-term outcomes: results from a retrospective study at the MD Anderson Cancer Center. Eur Urol 2013;64:307-13.

18 Moretto P, Wood L, Emmenegger U, et al. Management of small cell carcinoma of the bladder: Consensus guidelines from the Canadian Association of Genitourinary Medical Oncologists (CAGMO). Can Urol Assoc J 2013;7:44-56.

19 Bryant CM, Dang LH, Stechmiller BK, et al. Treatment of Small Cell Carcinoma of the Bladder With Chemotherapy and Radiation after Transurethral Resection of a Bladder Tumor. Am J Clin Oncol 2016;39:69-75. 
Rare disease

Copyright 2019 BMJ Publishing Group. All rights reserved. For permission to reuse any of this content visit https://www.bmj.com/company/products-services/rights-and-licensing/permissions/

BMJ Case Report Fellows may re-use this article for personal use and teaching without any further permission.

Become a Fellow of BMJ Case Reports today and you can:

- Submit as many cases as you like

- Enjoy fast sympathetic peer review and rapid publication of accepted articles

Access all the published articles

- Re-use any of the published material for personal use and teaching without further permission

Customer Service

If you have any further queries about your subscription, please contact our customer services team on +44 (0) 2071111105 or via email at support@bmj.com.

Visit casereports.bmj.com for more articles like this and to become a Fellow 